\title{
Biosensors: The Stability Problem
}

\author{
Tim D. Gibson
}

Enzyme Biotechnology Group, School of Biochemistry and Molecular Biology, University of Leeds, Leeds, West Yorkshire, LS2 9JT, UK

One of the main problems of many biosensors is their intrinsic stability. In some notable cases this has not been a drawback, allowing the successful commercialisation of glucose biosensors world-wide. However, the majority of enzymes used in biosensors are labile and require stabilisation to produce viable devices.

\section{Introduction}

The stabilisation of enzymes and other proteins is of great interest in a number of application areas where shelf life and stability during operation are required. In particular, applications which use very pure, high value proteins such as antibodies, analytical enzymes and the like, need to employ effective stabilisation technology primarily due to cost considerations and the availability of the proteins used. Lower cost, less pure proteins such as enzymes used in detergent applications can be used at higher levels to allow for some degradation during storage and use, but in practice even these bulk applications employ methods for stabilisation. The principle application of stabilisation systems in the production of sensors is the focus of this chapter, with a leaning towards the commercialisation aspects of biosensor devices. The definition of stability and several of the mechanisms of inactivation are included. Clearly the subject of biosensors is so diverse and so many different types have been described, a full review of how to stabilise all types is far outside the scope of this chapter. To give a rough overview, several examples of reported stability of some current biosensor formats have been included under the main heading of Biosensor Types. In addition, some specific experimental data of analytical enzyme stabilisation in biosensor formats carried out in our laboratories will also be given, with a brief discussion on the likely factors influencing stability of proteins in biosensors.

\section{Definition of Stability}

It is of prime importance to define the different types of stability at the very outset. Enzymes can be stabilised to improve shelf-stability or operational stability, and this may be done where enzymes are present in solution, as a dehy- drated powder (e.g. lyophilised) or immobilised on some sort of support, such as a biosensor surface.

SHELF-STABILITY may be defined as the enhancement or improvement of activity retention of an enzyme, protein, diagnostic or device when stored under specified conditions after manufacture. This parameter is vital for the commercialisation of labile materials that degrade over time. One of the most common examples of shelf-stability is in the food industry, where foodstuffs have a sell-by date stamped on the packaging. The same type of system is found on pharmaceuticals and often enzyme suppliers have a use-by or expiry date on their protein products. The stability of the labile biomaterial in biosensor devices is often one of the deciding factors as to the commercial viability of that particular sensor device.

OPERATIONAL STABILITY may be defined as the retention of activity of a protein or enzyme when in use. This is often the most quoted parameter in biosensor publications and it relates to the operating lifetime and reusability of a device. In many cases the lifetime of use of a sensor can be important, usually in an environment where monitoring of an analyte is required or when an analytical device incorporates a reusable sensor in the measuring process, e.g. the Yellow Springs Instrument glucose analyser [1].

Both shelf-stability and operating stability are important parameters, but in some cases the operational stability is irrelevant, whereas shelf-stability is crucial, such as in the manufacture of single use, disposable biosensors for glucose [2]. In some cases, notably with multi-use carbon paste biosensors both types of stability can be needed. The bulk of the paste not in contact with the analyte solution requiring shelf-stability and the tip of the device where the measurement occurs being in need of operational stability, if the device is to be used several times. These types of sensors are being developed and marketed by Gwent Sensors Ltd (GSL) based in South Wales, UK.

\section{Mechanisms of Inactivation of Enzymes}

The mechanisms of inactivation of proteins and enzymes are extremely varied. Figure 1 gives an overview of the different types of inactivation mechanisms that have been described for a number of proteins [3]. It can be seen that simple unfolding of the structure is only a small proportion of the methods by which enzymes and proteins inactivate. 


\author{
Unfolding (denaturation) \\ Loss of Co-Factor (FAD: Haem: PQQ) \\ Protein Aggregation \\ Poisoning - Irreversable Inhibition \\ Proteolosis \\ Substrates for Microorganisms \\ Chemistry of Protein Changing

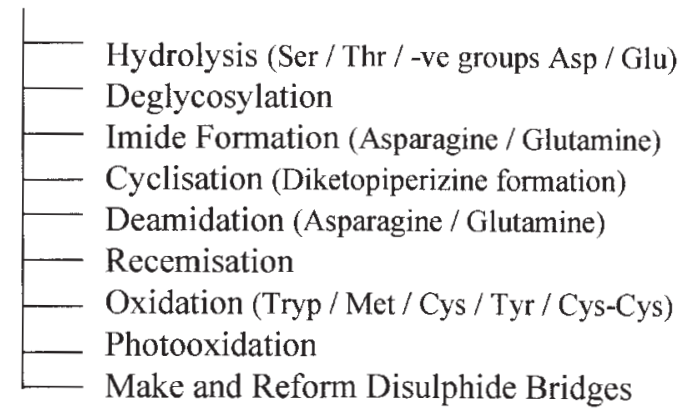

Figure 1. Methods of Inactivation of Enzymes.

The mechanisms of deactivation of enzymes are extremely varied and are summarised in the figure above. Enzymes can deactivate in a number of different ways depending on the conditions and it is entirely feasible that several deactivation mechanisms may occur simultaneously at any one time. In general dehydrated enzymes are more stable than dilute solutions and immobilised enzymes tend to exhibit better stability than native enzymes.

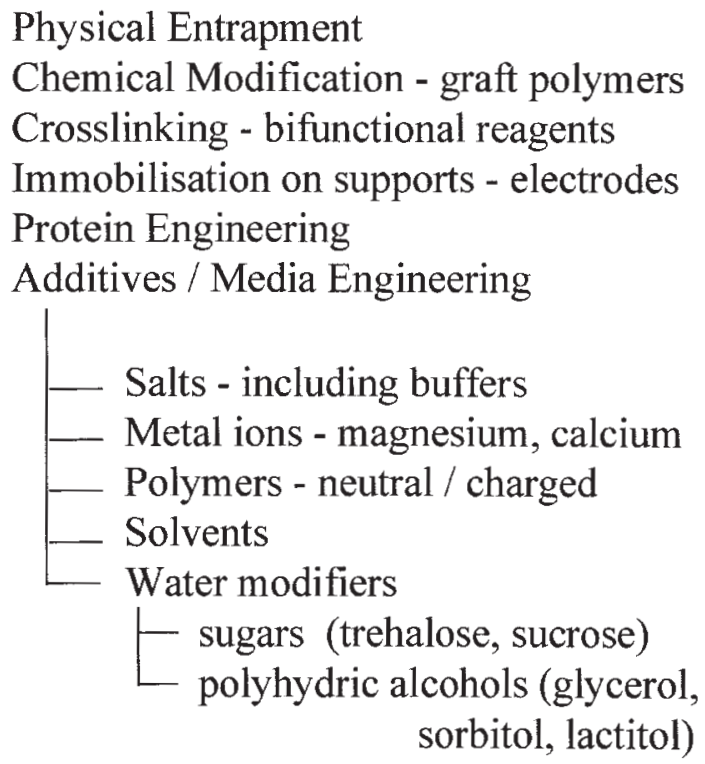

Figure 2. Summary of Methods of Enzyme Stabilisation.

There are literally hundreds of specific techniques that have been used to stabilise enzymes. The summary shown is a synopsis of the generic features of the methods used, rather than an exhaustive overview. Reviews of enzyme stabilisation techniques [4-6] give detailed descriptions of the specific methods used for a number of different enzymes.

\section{Methods of Stabilising Enzymes}

There are many different types of methods to influence the stability of an enzyme. Figure 2 contains a summary of the different methods that have been described. Some specific examples for the different types of stabilisation techniques will be given under the different headings included after this section. In general, stabilisation of the enzyme component is usually due to a combination of the different methods which effectively prevent the degradation route of the particular enzyme being used. The literature is full of examples of routes to the stabilisation of enzymes and it is not possible to detail them all here, however several good reviews are available in the literature [4-6].

\section{Biosensor Types}

In biosensor production, the enzyme or protein used is almost invariably immobilised, entrapped or crosslinked in some way so as to produce an intimate connection or communication between the enzyme and the transducer. The classical definition of a biosensor states: "A biosensor may be defined as a biological molecule that is intimately associated to or part of a transducer" [7]. Around this definition there are myriad's of system and format variations, with transducers varying from optical, electrochemical, piezoelectric and calorimetric. The main point focused on here is the need to stabilise the biomolecule used to provide the specificity of the response. Most successful biosensors in the commercial market that are used to detect and quantify substances employ enzymes as the biomolecule, with some sort of electrochemical measuring system as the transduction method. Glucose biosensors almost invariably use glucose oxidase as the enzyme, which has a very high specificity for $\beta$-D-glucose and is a protein having a high level of glycosylation on the surface of the molecule. The $3 \mathrm{D}$ structure has been published [8]. This enzyme is remarkably stable in a dry form, with the dry crystalline enzyme withstanding temperatures over $100^{\circ} \mathrm{C}$ for several minutes (personal communication from Dr J R Woodward). In biosensors the enzyme is also very stable in the dry state, thus allowing the manufacture and storage of devices without activity loss. However, the enzyme is not as stable in solution or during long term operation, as the flavin active site is reported to be gradually inactivated chemically by the hydrogen peroxide that is produced [9]. Immobilisation, membrane deposition and crosslinking all contribute to elevated operational stability of glucose biosensors, but in the main, single use, disposable glucose sensors have all but commandeered the marketplace. This is also sound marketing practice, as disposable means more sales of the sensor devices themselves.

Based on the figures displayed on the web site of Cranfield University Biotechnology Centre, (http://www.cranfield.ac.uk/biotech/), glucose biosensors hold around $90 \%$ of the world market share. The remainder 
of the biosensor market, where different enzymes are used consists of 1) other medical analytes such as lactate, urea and creatinine, 2) environmental analytes such as BOD (biological oxygen demand), pesticides and heavy metals and 3) others, consisting of fermentation monitoring, (e.g. alcohol, glutamate, glutamine, lactate) and instruments used to monitor direct molecular interactions (e.g. BiaCore, IAsys). These latter are not really analytical instruments but tools to detect and quantify the extent of molecular interactions and as such do not rely on enzymes for their sensor functionality.

Therefore the overall scope for stabilisation of enzymes for use in biosensors is relatively large if the subject is viewed from an academic standpoint, however in practice the number of biosensors that are likely to be produced and used as 'real' commercial devices is very much less. As the field of biosensors is extremely large and diverse, some of the different types described with some specific examples of biosensor stability will now be discussed under a series of distinct headings. In this way it is hoped that the types of stability protocols used for biosensor production will become more clear.

\section{Membrane Entrapped Biosensors}

The earliest type of biosensors to become available commercially were of this type. Yellow Springs Instruments Inc. pioneered the way, using a combination of cellulose acetate and microporous membranes fabricated as a sandwich to entrap a covalently crosslinked glucose oxidase enzyme layer. The stability of such crosslinked layers is very high, the enzyme being resistant to deactivation and reasonably compatible with glutaraldehyde, which is used as the crosslinker. A detailed treatise on amperometric membrane electrodes and their relative stabilities has been published [10].

Alternative oxidase enzymes lend themselves to this type of detection format, however their stability in a crosslinked format was found to be rather less than optimal. Using alcohol oxidase as the enzyme, the activity all but disappears during the crosslinking step and any residual activity left is destroyed rapidly on storage. Incompatibility with chemical crosslinkers, such as the rather aggressive glutaraldehyde can be a significant drawback in the formation of membrane biosensors. The stabilisation of alcohol oxidase in a dehydrated state for long term storage was accomplished in our laboratories in Leeds, UK using combinations of polyelectrolytes and polyalcohols added before the drying step, with the work patented in 1989 [11, 12]. This technology was adapted and transferred to the manufacture of membrane entrapped alcohol biosensors in 1990 during a collaborative project between YSI Inc. and our group. The alcohol oxidase based sensors are now manufactured using this method of stabilisation of the enzyme structure and a typical example of stability is shown in table I.

\section{Carbon Paste or Composite Biosensors}

Carbon paste biosensors have the advantage of being easy to prepare, adaptable to a variety of different enzyme based
Table I. Alcohol Oxidase Based Membrane Biosensor Stability.

$\begin{array}{ccc}\text { Incubation time. } & \text { No Stabilisers } & \text { Cationic } \\ \text { Days at } 37^{\circ} \mathrm{C} & \text { Added } & \text { Polyelectrolyte } \\ & & \text { Stabilisers Added }\end{array}$

$\%$ Remaining Activity Measured Relative to Mean Initial Activity

$\begin{array}{rcc}0 & 100 & 100 \\ 2 & 79 & 127.3 \\ 6 & 46.9 & 127 \\ 9 & 57.1 & 88 \\ 13 & 28.1 & 87.3 \\ 20 & 21.9 & 45.5\end{array}$

The membranes were stored dry and assayed for enzyme activity using the amperometric responses to $5 \mu \mathrm{l}$ injections of ethanol $\left(2.5 \mathrm{~g} . \mathrm{I}^{-1}\right)$ in a YSI model 27 glucose analyser. Electrode configuration comprised a platinum working electrode vs a silver/silver chloride reference electrode. Working potential $+0.65 \mathrm{~V}$. The biosensors were constructed with an upper membrane of nucleopore and a lower membrane of cellulose acetate, molecular weight cut-off 100 daltons. The enzyme was sandwiched between the membranes using a commercial immobilisation protocol (YSI Inc.) for the control and with the cationic polyelectrolyte combinations added to the immobilisation protocol for the stabilised membrane biosensors. The percentage activity retention was calculated by reference to an average initial response of freshly made biosensors.

systems and can be scaled up to give commercial quantities if required (along with associated problems of effective mixing, etc.). There are several groups around the world who have concentrated on this approach, together with the associated method of using composites, generally based on some type of material (e.g. epoxy resin, silicone resin), that is cured to give a solid matrix combined with carbon powder and/or other conductive materials. The group of Prof. Lo Gorton in Lund, Sweden has published a large number of examples, with several stabilisers being added that seem to improve both the shelf-stability and the operational stability of the biosensors [13-16]. Also carbon paste manufacture has been scaled up to commercial quantities by the group of Prof. Nabil El Murr at the University of Nantes and has been used in the production of a specialised device having a renewable surface [17]. The stability of the sensors produced has been shown to be very high, with full activity being retained for 1-2 years (personal communication). It is thought that the hydrophobic environment of the carbon paste reduces the relative water activity of the enzyme surface, thus mimicking the stabilisation effects seen with enzymes in organic solvents [18]. Khan and Wernet reported the formation of a multilayer composite lactate sensor having a shelf-stability of over 2 years at $-18^{\circ} \mathrm{C}$ and about a year at room temperature [19]. 


\section{Screen Printed Biosensors}

The main commercial success of recent years is associated with this type of biosensor. As previously mentioned the highest market share for biosensors is for screen printed electrodes for glucose. Such devices contain a number of different materials, designed to facilitate the process of screen printing, cause satisfactory mechanical stability and adhesion and create a stable microenvironment for the enzymes present. In the case of lactate oxidase, additives such as hydroxyethyl cellulose have been added to improve the rheology of the ink, with some general improvement in stability when the charged polymer Gafquat $755 \mathrm{~N}$ is also incorporated [20]. However the formulations of inks for the production of biosensors are usually closely guarded industrial secrets and the additives that are being used by the various manufacturers are, in the main, unknown to the end users. Where academic publications are concerned, the conductive inks used are often commercially formulated, with the enzyme layer being added as a separate coat on top. Examples include photopolymerisable entrapment of enzymes [21, 22], which is commercially used by Trace Biotech AG in their flow injection analysers and additions of DEAE-dextran and polyalcohols, shown to be effective in lactate biosensors [23].

\section{Biosensors Based on Self-Assembled Monolayers}

This technique has developed remarkably over the last few years with a large number of papers being produced reporting the attachment of enzymes onto gold surfaces using sulphur containing organics [24-26]. Secondary chemistry to form covalent immobilisation between the surface and the enzyme structure is generally used as the basis for biosensor production. The commercially available systems produced by BiaCore and similar companies utilise a number of reaction chemistries to immobilise the biomolecules used. A review of the formation and use of SAMS in sensors has been published [27].

The stability of the enzymes in the layers of SAMS can be extremely high by choosing the correct microenvironment, however the actual sulphur - gold bond can be destroyed at reducing potentials [28], thereby dictating the careful control of measuring system conditions when using these devices.

\section{Biosensors Based on Electropolymerised Films}

The technique of electropolymerisation of heterocyclic monomers, such as pyrrole or thiophene has also developed rapidly over the last 10 years. One of the first papers incorporating an enzyme into a polypyrrole film was published by Foulds and Lowe in 1986 [29]. The stability was reported to be fairly low, with a useful shelf-life of 21 days when stored in buffer at $4^{\circ} \mathrm{C}$. Since then there have been literally hundreds of papers reporting enzyme electrodes with electropolymerised films incorporated into the structure in some way or another. One in particular is worthy of note as the operational stability of the resulting electrode has been found to be extremely high. Koopal et al. reported direct electrochemistry between glucose oxidase and polypyrrole, by immobilisation of the enzyme onto a track etch membrane [30]. Commercial trials of such a membrane system, operating in flow injection mode have been done by an industrial laboratory, and have shown no loss of activity over six months of continuous use (personal communication). A review of the technique of electropolymerisation can be found in Adeloju and Wallace [31].

\section{Others Types of Biosensors and Immobilisation Methods}

\section{Electronic Wiring}

The technique of producing molecular wires was pioneered by Heller in the USA and involves the use of electron shuttling polymers containing osmium redox centres, that allow electrons to be conducted from the buried active sites of enzymes to the electroconductive surface of the transducer. The technique utilises the formation of molecular complexes of polycationic polymers with co-ordination chemistry and as such direct electrostatic interaction of the enzyme structure with the polycation can be observed using an agarose IEF technique, [personal communication]. The operational stability of glucose oxidase in the polymer matrix has been reported to be sufficient for use in implantable devices over a period of 3 days, with a suggested operational lifetime of 7 days [32].

\section{Electrostatic Immobilisation}

Immobilisation by attachment to a charged surface of an electrode has been reported by Strike et al. [33], where glucose oxidase was mixed with bovine serum albumin and electrochemically deposited onto the surface of a charged electrode. The resulting film was then covalently crosslinked with glutaraldehyde to produce the working sensor, giving an operational stability of over 70 days in use.

\section{Immobilisation by Lipid Attachment}

Though strictly not a biosensor paper, Kallury et al. reported a very unusual method of enzyme immobilisation using derivatised lipid chemistry [34]. The remarkable thing about the covalently attached urease used, was the observation that the thermal stability was enhanced to the level of being fully active after treatment at $100^{\circ} \mathrm{C}$ for 1 hour and also after 168 hours at $25^{\circ} \mathrm{C}$ when stored in a dry state. Comparative studies with urease immobilised onto the same surface by glutaraldehyde activated aminopropylsilane gave $85 \%$ and $93 \%$ activity losses under the same conditions.

\section{Langmuir-Blodgett Films}

This technique of producing thin, reproducible films of enzymes entrapped in a bilayer of supporting amphiphilic molecules has been shown to give very stable, heat resistant biocatalysts [35]. Such fabrication methods are very well defined and can be manipulated at the molecular dimension 


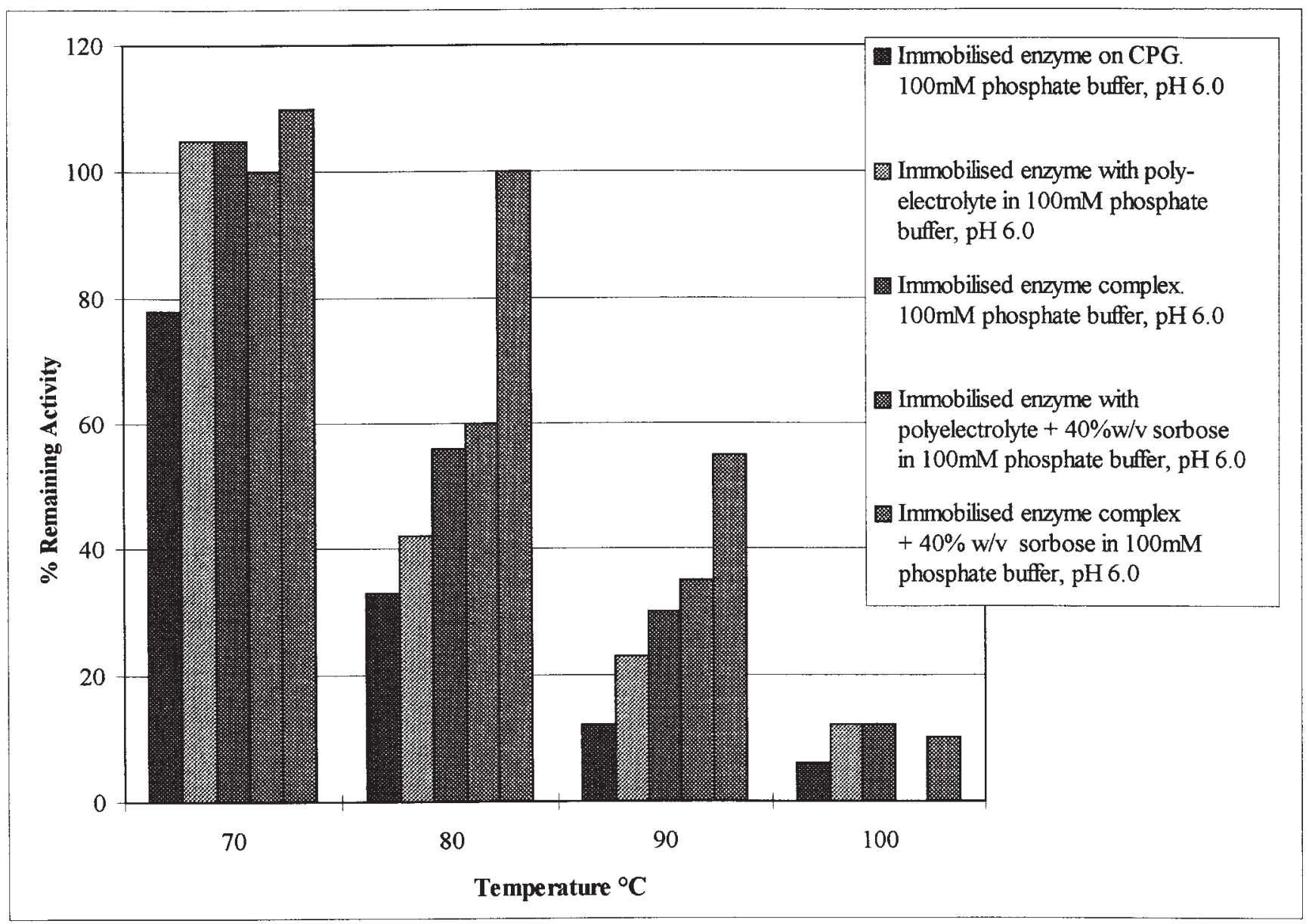

Figure 3. Stability of Immobilised Native Glucose Oxidase and Polycationic Enzyme Complexes.

Glucose oxidase or glucose oxidase-polyelectrolyte complex was immobilised on aminopropylsilane controlled pore glass after glutaraldehyde activation. The immobilised enzyme preparations were weighed into $5 \mathrm{mg}$ portions and incubated individually for 20 minutes at the respective temperatures shown, in $100 \mathrm{mM}$ phosphate buffer $\mathrm{pH} 6.0$, sorbose $(40 \% \mathrm{w} / \mathrm{v})$ was included in the same buffer when used. The results show that the enzyme is fairly stable at $70^{\circ} \mathrm{C}$ in all 5 preparations but as the temperature of incubation increases, the stability of the enzyme complex in the presence of sorbose is clearly much higher than the rest. The immobilised enzyme complex itself is marginally more stable than native immobilised enzyme to which a solution of polyelectrolyte is then added, possibly due to the formation of a more compatible microenvironment around the enzyme.

level, however large scale manufacture may be a drawback in this type of device.

\section{Immobilisation of Electrostatic Complexes}

This is a relatively new technique that has been adapted from the type of stabilisation systems developed in our group in Leeds. Immobilisation of enzyme-polyelectrolyte complexes onto glass surfaces show distinct improvements in the thermal stability, when compared to native immobilised enzyme [36]. This effect is further enhanced in the presence of polyalcohol solutions and also seem to allow the complete dehydration of the solid phase immobilised enzyme with full activity retention. Some practical data is shown in figure 3 using glucose oxidase as the model enzyme.

\section{Thermostable Extremophile Enzymes}

Jefferies $e t$ al. have produced a glutamate biosensor with an enzyme isolated from an extremophile, immobilised into a carbon paste matrix [37]. The enzyme was found to be fully active at temperatures of $60^{\circ} \mathrm{C}$ and unlike some examples of extremophile enzymes, the activity at lower temperatures was significantly high, allowing measurements to be carried out using standard conditions. In many cases highly thermostable enzymes have very low activity at ambient temperatures, leading to incompatibilities with the analytical systems being used. Such enzymes may be remarkable stable, but analytically they give such low signals so as to render them effectively useless for normal biosensor applications. 
Table II. Stabilisation of Different Enzyme Systems using Polyelectrolyte/Polyalcohol Combinations.

\begin{tabular}{|c|c|c|c|c|c|}
\hline \multirow[t]{2}{*}{ Enzyme. } & \multirow[t]{2}{*}{ Type } & \multicolumn{2}{|c|}{$\%$ Activity } & \multirow[t]{2}{*}{ Days. (n) } & \multirow[t]{2}{*}{ Temp } \\
\hline & & Day 0 & Day $n$ & & \\
\hline \multirow[t]{2}{*}{ Pyruvate kinase } & Control. & 47 & 8 & 29 & $37^{\circ} \mathrm{C}$ \\
\hline & + Stabilisers & 106 & 85 & 29 & $37^{\circ} \mathrm{C}$ \\
\hline \multirow[t]{2}{*}{ Hexokinase } & Control & 57 & 4 & 29 & $37^{\circ} \mathrm{C}$ \\
\hline & + Stabilisers & 160 & 129 & 29 & $37^{\circ} \mathrm{C}$ \\
\hline \multirow[t]{2}{*}{ Glucose-6-phosphate dehydrogenase } & Control & 80 & 31 & 29 & $37^{\circ} \mathrm{C}$ \\
\hline & + Stabilisers & 84 & 73 & 29 & $37^{\circ} \mathrm{C}$ \\
\hline \multirow[t]{4}{*}{ Fructose dehydrogenase } & Control & 100 & 27 & 155 & $4^{\circ} \mathrm{C}$ \\
\hline & + Stabilisers & 100 & 99 & 155 & $4^{\circ} \mathrm{C}$ \\
\hline & Control & 100 & 9 & 155 & $25^{\circ} \mathrm{C}$ \\
\hline & + Stabilisers & 100 & 76 & 155 & $25^{\circ} \mathrm{C}$ \\
\hline \multirow[t]{2}{*}{ Lactate dehydrogenase } & Control & 100 & 49 & 190 & $25^{\circ} \mathrm{C}$ \\
\hline & + Stabilisers & 100 & 110 & 190 & $25^{\circ} \mathrm{C}$ \\
\hline \multirow[t]{2}{*}{ Glucose dehydrogenase } & Control & 100 & 81 & 13 & $37^{\circ} \mathrm{C}$ \\
\hline & + Stabilisers & 108 & 112 & 13 & $37^{\circ} \mathrm{C}$ \\
\hline \multirow[t]{2}{*}{ Malate dehydrogenase } & Control & 14 & 2 & 20 & $37^{\circ} \mathrm{C}$ \\
\hline & + Stabilisers & 114 & 96 & 20 & $37^{\circ} \mathrm{C}$ \\
\hline \multirow[t]{2}{*}{$\beta$-Hydroxybutyrate dehydrogenase } & Control & 59.5 & 38.3 & 36 & $37^{\circ} \mathrm{C}$ \\
\hline & + Stabilisers & 105 & 91.3 & 36 & $37^{\circ} \mathrm{C}$ \\
\hline \multirow[t]{2}{*}{ Alcohol oxidase } & Control & 100 & 18 & 11 & $37^{\circ} \mathrm{C}$ \\
\hline & + Stabilisers & 100 & 102 & 162 & $37^{\circ} \mathrm{C}$ \\
\hline \multirow[t]{4}{*}{ Lactate oxidase } & Control & 100 & 28 & 300 & $37^{\circ} \mathrm{C}$ \\
\hline & + Stabilisers & 100 & 102 & 300 & $37^{\circ} \mathrm{C}$ \\
\hline & Control & 100 & 17 & 300 & $50^{\circ} \mathrm{C}$ \\
\hline & + Stabilisers & 100 & 64 & 300 & $50^{\circ} \mathrm{C}$ \\
\hline \multirow[t]{2}{*}{ Galactose oxidase } & Control & 117 & 38 & 16 & $37^{\circ} \mathrm{C}$ \\
\hline & + Stabilisers & 125 & 117 & 16 & $37^{\circ} \mathrm{C}$ \\
\hline \multirow[t]{2}{*}{ Cholesterol oxidase } & Control & 100 & 38 & 17 & $37^{\circ} \mathrm{C}$ \\
\hline & + Stabilisers & 100 & 93 & 17 & $37^{\circ} \mathrm{C}$ \\
\hline \multirow[t]{2}{*}{ Glycerol-3-phosphate oxidase } & Control & 110 & 60 & 15 & $37^{\circ} \mathrm{C}$ \\
\hline & + Stabilisers & 98 & 111 & 15 & $37^{\circ} \mathrm{C}$ \\
\hline \multirow[t]{2}{*}{ Choline oxidase } & Control & 63 & 4 & 15 & $37^{\circ} \mathrm{C}$ \\
\hline & + Stabilisers & 98 & 81 & 15 & $37^{\circ} \mathrm{C}$ \\
\hline \multirow[t]{2}{*}{ Uricase } & Control & 82 & 26 & 15 & $37^{\circ} \mathrm{C}$ \\
\hline & + Stabilisers & 91 & 100 & 10 & $37^{\circ} \mathrm{C}$ \\
\hline \multirow[t]{2}{*}{ Catalase } & Control & 85 & 65 & 22 & $37^{\circ} \mathrm{C}$ \\
\hline & + Stabilisers & 94 & 98 & 22 & $37^{\circ} \mathrm{C}$ \\
\hline \multirow[t]{2}{*}{ Horseradish peroxidase } & Control & 100 & 40 & 50 & $37^{\circ} \mathrm{C}$ \\
\hline & + Stabilisers & 100 & 102 & 50 & $37^{\circ} \mathrm{C}$ \\
\hline Acetylcholinesterase & Control & 100 & 10 & 43 & $37^{\circ} \mathrm{C}$ \\
\hline & + Stabilisers & 100 & 92 & 43 & $37^{\circ} \mathrm{C}$ \\
\hline Immobilised using Carbodiimide & Control & 100 & 54.5 & 76 & $37^{\circ} \mathrm{C}$ \\
\hline & + Stabilisers & 100 & 115.4 & 76 & $37^{\circ} \mathrm{C}$ \\
\hline$\beta$-Galactosidase & Control & 100 & 0 & 65 & $25^{\circ} \mathrm{C}$ \\
\hline & + Stabilisers & 100 & 90 & 65 & $25^{\circ} \mathrm{C}$ \\
\hline Serine Protease & Control & 100 & 22 & 56 & $50^{\circ} \mathrm{C}$ \\
\hline & + Stabilisers & 100 & 73 & 56 & $50^{\circ} \mathrm{C}$ \\
\hline
\end{tabular}

Activity is expressed in percentage relative to the initial activity,which in most cases has been taken as the $100 \%$ value of a freshly prepared dry enzyme sample. Where values other than $100 \%$ are recorded in the day 0 column, the zero time activity is related to the amount of activity of the solution of enzyme before dehydration. This gives a useful measurement of the amount of activity lost in the drying step. In all cases the stabilisers used were combinations of polyelectrolytes with polyalcohols taken from the patented process of Applied Enzyme Technology Ltd. 


\section{Analytical Enzyme Stabilisation in Biosensor Formats, Practical Examples}

The primary method of enzyme stabilisation used in our group is the manipulation of the environment of the native enzyme by additives, generally polyelectrolytes combined with polyalcohols and immobilisation using the chemistry of the surface groups. Initially it was demonstrated that the shelf-stability of dehydrated alcohol oxidase isolated from the methylotrophic yeast Hansenula polymorpha was markedly enhanced using these type of stabilisers [38-40]. The system has been tested with a number of enzymes including alkaline phosphatase, lactate oxidase, horseradish peroxidase, glucose oxidase, galactose oxidase, lactate dehydrogenase, malate dehydrogenase, hexokinase and acetyl cholinesterase and in all cases shelf-stability was observed to be elevated, often significantly so, table II.

Using these methods we have found it is also possible to further enhance the stability of recombinant, engineered enzymes which are already more stable than their native counterparts (unpublished data) and stability increases of several types of biosensors have been demonstrated [41-46]. The engineering of the media or the matrix surrounding the enzyme has the effect of producing an altered microenvironment in which the protein structure becomes stable. When the previous series of examples of biosensor types are considered, it is fairly obvious that the microenvironment of the enzymes being used is the crucial factor in almost all cases. The creation of charged, hydrophobic or hydrophilic environments all have significant influences on the stability of the final device produced. Where oxidation of the enzyme structure is one of the primary reasons for deactivation, the creation of reducing microenvironments may be an option to improve stability [47]. However such conditions may be incompatible with enzyme systems that produce oxidising products, e.g. oxidases that produce hydrogen peroxide. The effect of the type of immobilisation method used is shown clearly in the case of pesticide biosensors made using acetylcholinesterase as the active biocomponent. When glutaraldehyde is used as the immobilisation agent the result-

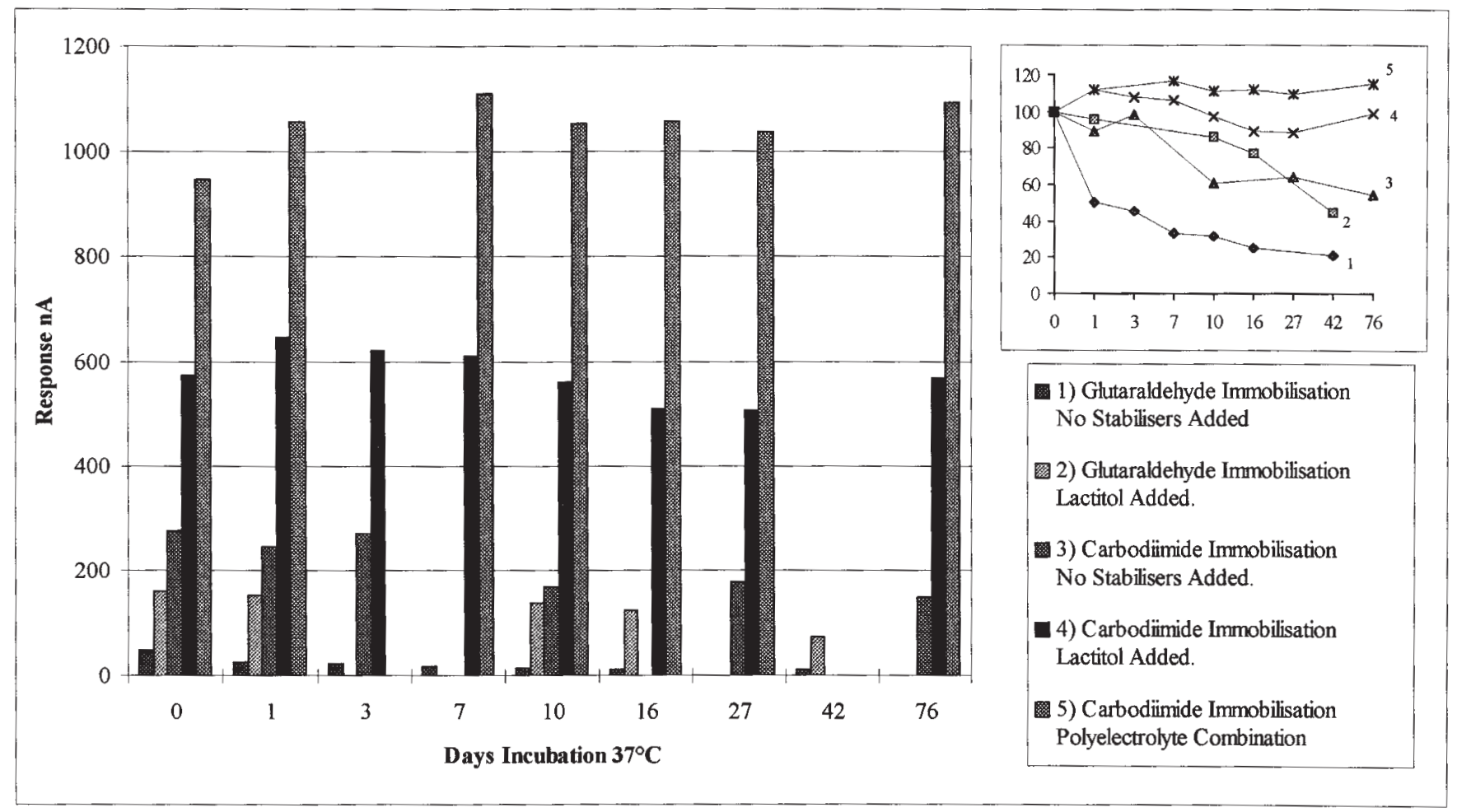

Figure 4. Immobilisation Matrix Effect on Biosensors Based on Acetylcholinesterase.

The stability of the acetylcholinesterase based biosensors is shown to depend very much on the type of immobilisation used in the manufacturing step. When glutaraldehyde is used as a crosslinker the enzyme activity is low, indicated by the very low amperometric response. Adding lactitol to the enzyme before crosslinking improved the stability, but still the responses were below 200nA. Using carbodiimide coupling the activity improved to around $250 \mathrm{nA}$ and adding lactitol increased the activity $2 \frac{1}{2}$ times, indicating a higher enzyme survival rate. A further improvement occurs when an anionic polyelectrolyte is incorporated into the manufacturing process, giving an approximate 4 fold current increase over unstabilised carbodiimide immobilised sensors. The insert shows the data plotted as a percentage survival rate over time at $37^{\circ} \mathrm{C}$. The stability trend is the same, however it can be seen that the data could be easily misinterpreted as it is not clear form the percentage graph the level of amperometric response observed. 
ing catalytic currents are low and the stability is poor. Carbodiimide immobilisation of the enzyme onto the carbon matrix improves the stability dramatically and also increases the currents significantly, figure 4. A fuller discussion of these effects is given in Rippeth et al. [48] and Gibson and Steele [49].

\section{Likely Factors of Enzyme and Protein Stabilisation}

Based on the many examples from the literature and the experiences of the research carried out at Leeds it is suggested that one of the major contributory factors of enzyme stability is the control of the relative water activity at the enzyme surface, whether the enzyme is dissolved, immobilised or (in the case of organic solvents) suspended. This factor is likely to be the single most important parameter in promotion of structural stability of enzymes. In adding polyhydric alcohols to aqueous solutions, the bulk and surface water activity is modified relative to the absolute concentration of the additive and it is well known that stabilisation effects observed are dependant on the concentration of polyalcohol present [50-51]. Also enzyme activity in organic solvents where the water activity is carefully controlled is nothing short of remarkable in many cases [52]. When used in combination with additives promoting electrostatic interactions (polyelectrolytes) or surface chemical interactions leading to immobilisation or crosslinking, the efficacy of polyalcohols is usually enhanced significantly, indicating synergy of action at the surface of the protein structure thereby stabilising the enzyme overall. The solvation characteristics of an enzyme are likely to be changed significantly when associated into an enzyme-polyelectrolyte complex and as such will interact differently with polyalcohol solutions leading to elevated stability. This also indicates that the electrostatic microenvironment may be very important as well as the water content. This is supported by observations on glucose biosensors, where glucose oxidase was associated with redox active polyelectrolyte stabilisers, the stability of the biosensor response was greatly influenced by the length of time the biosensors were polarised. Unpolarised biosensors remained active for far longer than polarised ones [53]. Khan and Wernet also reported a loss of stability at higher polarisation potentials [19].

In conclusion, where enzyme biosensor stability is concerned it is thought that the surrounding environment of the enzyme and the surface interactions occurring are likely to be just as important, if not more so, than the actual amino acid sequence and corresponding secondary and tertiary structure of the enzyme molecule being used. In the field of biosensor design, one of the great strengths is in the broad, multidisciplinary knowledge base of the science involved. The novel approaches designed to produce working biosensors generally incorporate aspects of stability and the requirements needed for enzyme microenvironment manipulation. However, more often than not, these aspects are included without specific rational design, as the stability of biosensors often seems more of a secondary consideration, relative to the electrochemistry and the analytical characteristics of the devices produced. In the commercial world, many techniques have to be introduced to overcome manufacturing problems associated with scale-up. The product produced has to be guaranteed to work analytically and has to be stable before and in use. Here is the real challenge, to introduce rational stabilisation design as part of the development protocol towards manufacture of viable, commercially available biosensors. To facilitate this process a university spin-off company, Applied Enzyme Technology Ltd, specialising in enzyme stabilisation was created in 1994. The patented technology coming from our academic group is owned by the company and there is now a route to directly introduce commercially viable protocols into the biosensor industry, based on rational design of enzyme structure at the industrial level.

\section{Acknowledgments}

I would like to acknowledge Dr Ben Appleton, Dr John Rippeth and Mr John Hulbert, who have done the majority of the work in biosensor stabilisation at Leeds and all the $\mathrm{PhD}$ students who have provided stabilisation data for different enzymes. Dr John Woodward for communicating his results on glucose oxidase and Prof. Nabil El Murr for the information on the carbon paste electrodes. In addition, Dr Ioanis Katakis for discussions on polyelectrolyte binding to glucose oxidase and Dr Dominic Steele for help in displaying the molecular graphics of the enzymes being stabilised.

\section{References}

1 Newman, D. P. The Yellow Springs Instrument Company Inc. US Patent 3, 979, 274, 1976.

2 Hill, H. A. O.; Higgins, I. J.; McCann, J. M.; Davis, G. US Patent 5,682,884, 1997

3 Rhodes, C. T.; Franks, F.; Shefter, E.; Pikal, M. J. Stability of Protein Drugs, Biologics and Devices, Centre for Professional Advancement (Amsterdam), 14 -15 September 1992.

4 Klibanov, A. M. Anal. Biochem. 1979, 93, 1-25.

5 Schmid, R. D. Advanced Biochemical Engineering, 1979, 12, 41-118.

6 Gianfreda, L.; Scarfi, M. R. Molecular \& Cellular Biochemistry, 1991, 100, 97-128.

7 Turner, A. P. F.; Karube, I.; Wilson, G. S. Eds. Biosensors. Fundamentals and Applications, Oxford Science, (1987).

8 Hecht, H. J.; Kalisz, H. M.; Hendle, J.; Schmid, R. D.; Schomburg, D. J. Mol. Biol. 1993, 229, 153-172.

9 Greenfield, P. F.; Kittrell, J. R.; Laurence, R. L. Anal. Biochem. 1975, 65, 109-124.

10 Coulet, P. R.; Bardeletti, G.; Séchaud, F. In: Bioinstrumentation and Biosensors (Wise D L. ed) Marcel Dekker Inc. New York, 1991, 753-793. 
11 Gibson, T. D.; Woodward, J. R. International patent PCT/GB89/01346, (1989).

12 Gibson, T. D.; Woodward, J. R. International patent PCT/GB91/00443, (1991).

13 Spohn, U.; Narasaiah, D.; Gorton, L.; Pfeiffer, D. Anal. Chem. 1996, 319, 79-90.

14 Narasaiah, D.; Spohn, U.; Gorton, L. Anal. Letters 1996, 29, 181-201.

15 Kacaniklic, V.; Johansson, K.; Marko-Varga, G.; Gorton, L.; Jonsson-Pettersson, G.; Csoregi E. Electroanalysis 1994, 6, $381-390$.

16 Spohn, U.; Narasaiah, D.; Gorton, L.; Pfeiffer, D. Anal. Chem. Acta 1996, 319, 79-90.

17 El Murr, N.; Slilam, M. US Patent 5,272,087, 1993.

18 Zaks, A.; Klibanov, A. M. J. Biol. Chem. 1988, 263, 80178021.

19 Khan, G. F.; Wernet, W. Anal. Chem. 1997, 69, 2682-2687.

20 Collier, W. A.; Hart, A. L. Australasian Biotech. 1997, 7, 9395.

21 Rohm, I.; Kunnecke, W.; Bilitewski, U. Anal. Chem. 1995, 67, 2304-2307.

22 Rohm, I.; Genrich, M.; Collier, W.; Bilitewski, U. Analyst 1996, 121, 877-881.

23 Hart A L, Janssen D and Cox, H. Biosen. Bioelec. 1996, 11, 833-837.

24 Dong, S. J.; Li, J. H. Bioelectrochem. and Bioenegetics 1997, 42, 7- 13.

25 Disley, D. M.; Cullen, D. C.; You, H.-X.; Lowe, C. R. Biosen. Bioelec. 1998, 13, 1213-1225.

26 Lotzbeyer, T.; Schuhmann, W.; Schmidt, H. L. Bioelectrochem. and Bioenegetics 1997, 42, 1-6.

27 Wink, Th.; van Zuilen, S. J.; Bult, A.; van Bennekom, W. P. Analyst 1997, 122, 43R-50R.

28 Beulen, M. W. J.; Kastenberg, M. I.; van Veggle, F. C. J. M.; Reinhoudt, D. N. Langmuir 1998, 14, 7463-7467.

29 Foulds, N. C.; Lowe, C. R. J. Chem. Soc. 1986, 82, 12591264.

30 Koopal, C. G. J.; Feiters, M. C.; Nolte, R. J. M.; Deruiter, B.; Schasfoort, R. B. M. Biosen. Bioelec. 1992, 7, 461-471.

31 Adeloju, S. B.; Wallace, G. G. Analyst 1996, 121, 699-703.

32 Csoregi, E.; Schmidktke, D. W.; Heller, A. Anal. Chem. 1995, 67, 1240-1244.

33 Strike, D. J.; de Rooij, N. F.; Koudelka-Hep, M. Sensors and Actuators 1993, 13-14, 61-64.
34 Kallury, K. M. R.; Lee, W. E.; Thompson, M. Anal. Chem. 1992, 64, 1062-1068.

35 Nicolini, C. Ann. N. Y. Acad. Sci. 1996, 799, 297-310.

36 Appleton, B.; Gibson, T. D.; Woodward, J. R. Sensors and Actuators B. 1997, 43, 65-69.

37 Jefferies, C.; Pasco, N.; Baronian, K.; Gorton, L. Biosen. Bioelec. 1997, 12, 225-232.

38 Gibson, T. D.; Higgins, I. J.; Woodward, J. R. Analyst 1992, 117, 1293-1297.

39 Gibson, T. D.; Hulbert, J. N.; Woodward, J. R. Anal. Chim. Acta 1993, 279, 185-192.

40 Gibson, T. D.; Hulbert, J. N.; Pierce, B.; Webster, J. I. In: Stability and Stabilization of Enzymes (van den Tweel W J J, Harder A and Buitelaar R M. eds) Elsevier, Maastricht, 1993, 337-346.

41 Gibson, T. D.; Hulbert, J. N.; Parker, S. M.; Woodward, J. R.; Higgins, I. J. Biosen. Bioelec. 1992, 7, 701-708.

42 Gibson, T. D.; Woodward, J. R. In Biosensors and Chemical Sensors, (Eldman P G and Wang J. eds) ACS Books, 1992, 40-55.

43 Gibson, T. D.; Pierce, B. L. J.; Hulbert, J. N.; Gillespie, S. Sensors and Actuators B 1996, 33, 13-18.

44 Chaniotakis, N. A.; Gavalas, V. G.; Gibson, T. D. Biosen. Bioelec. 1998, 13, 1205-1211.

45 Gibson, T. D.; Pierce, B. L. J.; Parker, S. M. In: Biosensors for Food Analysis (A.O.Scott ed) The Royal Society of Chemistry, Leeds, 1998, 46-53.

46 Woodward, J. R.; Brunsman, A.; Gibson, T. D.; Parker S. In: Biosensors for Food Analysis, (A.O.Scott ed) The Royal Society of Chemistry, Leeds, 1998, 71-90.

47 Kricka, L. J.; Carter, T. J. N. Clin. Chim. Acta. 1977, 79, 141147.

48 Rippeth, J. J.; Gibson, T. D.; Hart, J. P.; Hartley, I. C.; Nelson, G. Analyst 1997, 122, 1425-1429.

49 Gibson, T. D.; Steele, D. Molecular Dimensionality, Surface Chemistry and 3D Enzyme Structure Proceedings of Eurosensors XII, September 1998, 2, 805-808.

50 Monsan, P.; Combes, D. Ann. N. Y. Acad. Sci. 1984, 434, 4860.

51 Ye, W. N.; Combes, D.; Monsan, P. Enzyme Microb. Technol. 1988, 10, 498-504.

52 Zaks, A.; Klibanov, A. M. Science 1984, 224, 1249-1251

53 Rippeth, J. J. Enzyme Polymer Matrices For Production and Stabilisation of First and Second Generation Biosensors. PhD Thesis, University of Leeds, 1998. 